\title{
Health beliefs and barriers related to HIV prevention and screening among students of the University of Vlora: a cross-sectional study
}

Rezarta Lalo ${ }^{1 *}$ (D) Gjergji Theodhosi ${ }^{2}$ and Alberta Breshanaj ${ }^{3}$

\begin{abstract}
Background: Previous researchers have found that young university students can have a high level of knowledge about HIV/AIDS infection, but they are still not utilizing the existing HIV prevention methods. As a result there is a need to determine which factors and barriers influence the use of existing HIV screening and prevention methods among students of the University of Vlora in Albania.

Methods: This was a cross-sectional study conducted among university students in the district of Vlora, Albania from April to June 2018. Stratified, multi-stage sampling technique was used to select randomly study subjects. A structured, self-administered questionnaire was used for data collection. Bivariate and multivariate logistic regression analysis was employed to reflect the relationship between variables.

Results: The mean age of the participants (710) was $20.85 \pm 2.1$ years. $38 \%$ of them believe that chances of getting HIV would not stop them to have sexual intercourse with more than one partner, $69 \%$ report that using a condom seems like an insult to their partner. 78\% of the students with sexual experience didn't used Voluntary Counseling and Testing services. The students from the rural area ( $A O R=0.50,95 \% \mathrm{Cl}[0.30-0.82])$ and those of first academic year (AOR second/first year $=2.31,95 \% \mathrm{Cl}[1.33-3.99]$, AOR third/first year $=1.18,95 \% \mathrm{Cl}[0.65-2.13]$ ) were less likely to use HIV service.

Conclusions: The findings reveal that health beliefs and barriers are good predictors of the preventive behaviours toward HIV infection. The survey has provided evidence to suggest that creating awareness about HIV prevention among student community, especially those from non-health sciences and rural areas could contribute to increased uptake of the VCT services, the condom use and to reduce the identified stigmatizing barriers.
\end{abstract}

Keywords: Barriers, Health beliefs, HIV/AIDS, Screening, Sexual health, Student

\footnotetext{
*Correspondence: rezarta_lalo@yahoo.com; rezarta.petani@univlora.edu.al

${ }^{1}$ Faculty of Public Health, Department of Healthcare, University of Vlora

"Ismail Qemali", Skelë, Rruga Kosova, 9400 Vlorë, Albania

Full list of author information is available at the end of the article
}

(c) The Author(s). 2020 Open Access This article is licensed under a Creative Commons Attribution 4.0 International License, which permits use, sharing, adaptation, distribution and reproduction in any medium or format, as long as you give appropriate credit to the original author(s) and the source, provide a link to the Creative Commons licence, and indicate if changes were made. The images or other third party material in this article are included in the article's Creative Commons licence, unless indicated otherwise in a credit line to the material. If material is not included in the article's Creative Commons licence and your intended use is not permitted by statutory regulation or exceeds the permitted use, you will need to obtain permission directly from the copyright holder. To view a copy of this licence, visit http://creativecommons.org/licenses/by/4.0/. The Creative Commons Public Domain Dedication waiver (http://creativecommons.org/publicdomain/zero/1.0/) applies to the data made available in this article, unless otherwise stated in a credit line to the data. 


\section{Background}

There are many minor and major factors that help the HIV/AIDS (Human Immunodeficiency Virus/Acquired Immunodeficiency Syndrome) epidemic in national, regional, continental and global level. Even though the epidemics follow various courses in different countries, there are some common features as for the transmission and distribution method, which help us estimate the fast spreading of the virus globally [1]. The factors that raise the vulnerability to HIV include some cultural practices, the inappropriate control of health and resources, especially on health care, education and wellbeing, religious beliefs, poor governing, migration, conflicts, urbanizing, and stigma of the marginalized groups [2].

A significant diminuition in new cases of HIV infections has occured internationally, in specific 16\% during these last 10 years, along with a reduction in number of deaths due to AIDS, 48\% since 2005 [3]. Nonetheless, there are some countries around the world that have shown a different trend. In 2016, the majority of the European countries reported 160,453 new HIV cases in the World Health Organisation. This continued trend corresponds to a rate of 18,2 per 100,000 people [4]. While Albania remains a low HIV prevalence country, the rise of new HIV diagnoses in Albania is concerning. The European Centre for Disease Prevention and Control (ECDC) listed Albania third in the region in terms of affected individuals. According to ECDC, 94 albanian people had been affected by the HIV virus during 2017. Most of the cases are undergoing the developing phase of a disease, and the sum total of diagnosed people has gone to 1400. In Albania, as in the wider region, young people seem to be particularly vulnerable to HIV. The number of reported HIV- positive cases for youth aged $15-29$ was about $22 \%$ of the total number of cases $[4,5]$.

A positive answer to the spread of HIV/AIDS starts with prevention [6]. Our country, Albania has followed the same line with the objectives of World Health Organization (WHO) and other scientific international institutions on HIV/AIDS prevention [7]. A lot of awareness campaigns are conducted in order to increase the youth awareness, so that they may be oriented toward a healthier life style, adopt positive behavior and increase the request for reproductive sexual services [8].

Various studies have reported that university students, who are mostly young people, rarely use existing HIV/ AIDS preventive methods [9]. In Albania some studies report that the prevalence of not using condoms during the first sexual act is high in this age group [10] and the main reason is the pregnancy avoidance. Only a small percentage of the young people use the condom to avoid sexually transmitted diseases (STD) and HIV/AIDS [8]. In order to understand the behavior of young people who do not use condoms, it is essential to determine the beliefs and the perceived barriers that predispose condom use and non-use [11-13].

Another element which should be taken into consideration during the studies is the utilization of health services among the youth. Voluntary counseling and testing (VCT) is an effective approach for facilitating behavioral change, reducing unprotected sex around both preventing HIV as well as getting early access to care and suppor [14]. In Albania, VCT are services offered to all people who want to know their HIV status and a redesign of them is needed to better target and outreach to vulnerable populations. The data show that the use of health services from the youth is very low. Seeking an HIV test may be more difficult for young people because many lack experience and some barriers in accessing VCT services $[15,16]$. The aim of the present study is therefore to evaluate health beliefs and barriers related to HIV prevention and screening with an emphasis on the association between VCT uptake and explanatory factors among students of the University of Vlora. To this end, this article addresses the following question: Will students' beliefs influence health services uptake?

\section{Methods}

Study area, study design and study period

A cross-sectional study was conducted among university students, age $\geq 18$ years, in the district of Vlora, Albania from April to June 2018. The study followed the consolidated criteria for observational research (STROBE).

\section{Sample size and sampling technique}

Due to the lack of a similar study in this area, we used the Cochran formula to determine the sample size, which according to the calculations made, resulted in 384. As there is a total population of 8151 students in the university of Vlora, we made an adjustment [14] using the formula: $n f=n i /[1+(n i / N)]$, where $n i$ is the sample size resulted by the Cochran formula and $\mathrm{N}$ is the sum total of all students in the University of Vlora. Using a 5\% margin of error at a $95 \%$ confidence level, the required sample size was 367 .

Multi-stage sampling technique was used to select study subjects. Firstly, the students were stratified by their field of study as health science and non health science. Secondly, two departments from health science and four departments from non health science were selected using simple random sampling based on proportion. Thirdly, the students in each field of study were further stratified by their year of study assuming that their field of study and duration of stay in the campus affect their VCT utilization. Finally, the students were selected from each batch proportionally by simple random sampling technique using computer generated random numbers. 


\section{Data collection}

Data was collected using an instrument in the form of a self-administered questionnaire of type Knowledge, Attitude, Practice and Belief survey (KAPB) which comprised four sections. The first section included the sociodemographic characteristics of participants, Section II presented students' perceptions related to health beliefs and barriers of screening methods, Section III related to students' knowledge about the preventive methods and Section IV on students' sexual practices and VCT uptake. The perceptions related to Health Beliefs and Barriers were assessed using a ten items questionnaire and the evaluation was 1 score for the correct answer. Students could choose from 3 options for each question: "correct", "incorrect" and "don't know". The "don't know" answers were treated as incorrect answers in the analysis. An index of Health Beliefs and Barriers was created that ranged from 0 to 10 , with higher scores indicating more correct perceptions. The perceptions' classification was done in these levels: 6-10 points "correct" perception and $0-5$ points "incorrect" perception. Knowledge on preventive methods was assessed by single question as "Using the condom during the sexual act may reduce the risk of HIV infection". Sexual practices were assessed using three items of section III which includes sexual experience, the age of first sexual intercourse and number of sexual partners. VCT utilization was assessed by single question as "Did you used VCT service?" which respond in "Yes" or "No".

The items were adapted from previous researches [14, 17-22] and developed for use in Albania. To increase the validity of the tool and the reliability of the statements, Section I to IV were based on various publically accessible survey instruments, such as the HIVKnowledge Questionnaire [19], Attitudes about HIV Infection Questionnaire [20] adapted from a measure reported by Alawad, et al., AIDS Health Belief Scale (AHBS), developed by Zagumny and Brady [21], to measure the four components of the Health Belief Model (HBM), The Barriers to HIV testing scaleKarolinska version [22] reported by Wiklander et al.

The questionnaire is originally prepared in English language and then translated to Albanian and again retranslated to English by two language experts for consistency.

\section{Data analysis}

An expert in statistic was used for data coding and analyses to enhance the research validity. For statistical analysis of the data was used statistical program SAS (Statistical Analysis System) version 9.1. For categorical variables were reported absolute numbers and percentages respective. To assess the association between categorical variables was used Chi-square statistical test. $P$-value $\leq 0.05$ was taken as cut of value to be significant.
A bivariate logistic regression analysis was used to reflect the relationship between the dependent variables (perception of health beliefs, VCT utilization) and the independent factors (socio-demographic, sexual behaviors). Bivariate analysis was also employed to assess the association between VCT utilization (dependent variable) and perceived barrier to HIV testing (independent variable); knowledge on preventive method (independent variable) and perceived barrier related to condom use (dependent variable). Variables with a bivariate association of $p$ value less than 0.05 were entered into the multivariate analysis. When we choose to analyse above variables using multivariate logistic regression, we also considered other criteria for its use: Dependent variable is measured in nominal scale, independent variables are nominal or continuous (number of sexual partners), observations are independent, lack of multicollinearity is controlled by calculating the Spearman correlation coefficient, by first coding the nominal variables. Adjusted odds ratios (AORs) and 95\% confidence intervals (CIs) were presented along with the corresponding $p$-value in the multivariate analysis.

\section{Results}

\section{Socio-demographic characteristics of participants}

The mean age of the participants was $20.85 \pm 2.1$ years. Acoording to gender, about $56 \%$ of the participants were females and $44 \%$ males, related to residence, $66 \%$ of the students live in the city and $34 \%$ in the village. Related to civil status $83 \%$ are single, $7 \%$ are married, $9 \%$ live with another partner, $1 \%$ divorced. $68 \%$ of the participants have had sexual experience.

\section{The perception of health beliefs and barriers related to HIV/AIDS is shown in Table 1.}

A total of 710 students completed the section on students' perceptions of Health Beliefs and Barriers related to HIV/AIDS of the questionnaire. We found out that $69 \%$ of the students report that using a condom seems like an insult to their partner, $47 \%$ believe that a person infected with HIV can be identified from his/her thin look, 38\% believe that chances of getting HIV would not stop them to have sexual intercourse with more than one partner and only $26 \%$ of participants would not get tested for HIV because of fear of losing partner.

The relationship between the perception of health beliefs \& barriers and socio demographic variables is shown in

Table 2.

Based on the scoring of perceptions' classification, 76\% of participants (540 students) had correct perception related to health beliefs \& barriers. The results of bivariate logistic regression analysis for the relationship between the perception of health beliefs \& barriers and socio 
Table 1 The evaluation of health beliefs \& barriers related to HIV/AIDS among students of University of Vlora

\begin{tabular}{|c|c|c|c|c|}
\hline \multirow[t]{2}{*}{ The perception of health beliefs \& barriers related to HIV/AIDS } & \multicolumn{2}{|c|}{$\begin{array}{l}\text { Correct } \\
\text { answer }\end{array}$} & \multicolumn{2}{|c|}{$\begin{array}{l}\text { Incorrect } \\
\text { answer }\end{array}$} \\
\hline & No. & $\%$ & No. & $\%$ \\
\hline 1. I believe that a person should be worried about HIV/AIDS only if he/she starts to get sick. & 476 & 67.04 & 234 & 32.96 \\
\hline 2. I believe that a person infected with HIV can be identified from his / her thin look. & 379 & 53.38 & 331 & 46.62 \\
\hline 3. I believe that taking a test for HIV one week after having sex will tell a person if she or he has HIV. & 486 & 68.45 & 224 & 31.55 \\
\hline 4. I believe that HIV is a punishment for immoral behavior. & 629 & 88.60 & 81 & 11.40 \\
\hline 5. I believe that clients who get HIV through illegal behavior (e.g., sex work), should not be treated at hospitals and clinics. & 442 & 62.25 & 268 & 37.75 \\
\hline 6. I believe that religious people cannot get infected with HIV & 558 & 78.69 & 152 & 21.41 \\
\hline $\begin{array}{l}\text { 7. The chances of getting HIV would not stop me to have sexual intercourse with more than one } \\
\text { partner. }\end{array}$ & 440 & 61.97 & 270 & 38.03 \\
\hline 8. Using a condom seems like an insult to my partner. & 218 & 30.70 & 492 & 69.30 \\
\hline 9. I would not get tested for HIV because I was afraid of losing my partner. & 520 & 73.34 & 188 & 26.66 \\
\hline 10. I would not go to a local clinic to be tested for HIV because then everyone would know my status. & 524 & 73.91 & 186 & 26.19 \\
\hline
\end{tabular}

demographic variables showed that there was a significant statistical association with variables "field of study" (Chi square $p=0.015<0.05)$ and "academic year" ( $p=$ $0.016)$. The results found that health science students were 1.6 times more likely than non health sciences ones to have correct perceptions $(\mathrm{OR}=1.61$; 95\% CI, [1.12$2.32])$. Furthermore, $82 \%$ of the students of the second year followed by those of the third year (78\%) and the first year (68\%) resulted to have correct perception of beliefs and barriers. According to bivariate logistic regression, the odds (OR second year/first year $=1.80$; $95 \%$ CI, [1.18-2.73], OR third year/first year $=1.53$; $95 \% \mathrm{CI}$, [1.01-2.32]) of the students of second year and third year were respectively about 80 and 53\% higher than students of first year to have correct perception of barriers. While the analysis of association between the perception of beliefs \& barriers and the other socio demographic variables including "sexual experience" found that there was no statistically significant relationship.

Referring to multivariate logistic regression the sociodemographic factors associated with correct perceptions were: field of study $(\mathrm{AOR}=1.67 ;[1.15-2.41])$ and academic year (AOR second year/first year $=1.88$; $[1.23-$ 2.87], AOR third year/first year $=1.52$; 95\% CI [1.002.31]). These results showed that the students of second and third year were respectively 88 and $52 \%$ more likely than first year ones to have correct perceptions. Also, the health science students were $67 \%$ more likely than non health sciences ones to have correct perceptions.

Regarding the association between students' knowledge about the preventive methods and the perceived barrier, shown in Table 3, the results found that $75 \%$ of students (411) who agreed that condom use reduces the risk of HIV infection also believe that using it may seem like an insult to partner. The bivariate analysis with logistic regression between above variables showed that the students with correct answers about knowledge on preventive methods related to HIV infection were $65 \%$ less likely to have positive perceived barriers compared to those with incorrect knowledges $(\mathrm{OR}=0.35$, 95\% CI [0.24-0.50]).

Our study, also analyzed the association between VCT uptake and explanatory factors among students with sexual experience, considered as a subgroup of students with potential risky sexual behaviors. This association is shown in Table 4. According to the association between students' sexual practices and VCT uptake, the majority of the students with sexual experience (78\%) didn't used VCT services. One hundred six students declared that are tested for HIV, from which $47 \%$ females and $53 \%$ males. So, there is a difference of $5.67 \%$ in favour of males. The results of bivariate logistic regression analysis for the relationship between VCT uptake and socio demographic variables showed that there was a significant statistical association with variables "residence" $(p=0.007<0.05)$ and "academic year" ( $p=$ $0.001<0.05)$. According to residence, $26 \%$ of participants from urban areas and 15\% from rural areas reported that are tested for HIV. Furthermore, 31\% of the students of the second year followed by those of the third year (18\%) and the first year (17\%) resulted to have testing for HIV. The odds of VCT uptake among students from the rural areas were 2 times lower than those from urban areas $(\mathrm{OR}=0.48,95 \% \mathrm{CI},[0.29-0.80])$. As for academic year, the students of second year were $13 \%$ more likely than of first year to have HIV testing (OR = $1.13 ; 95 \%$ CI [0.63-2.04]). The students of third year were 2.29 times more likely than of first year ones to have $\mathrm{HIV}$ testing $(\mathrm{OR}=2.29 ; 95 \% \mathrm{CI},[1.33-3.96])$. 
Table 2 The association between the perception of health beliefs \& barriers, socio demographic variables and sexual experience of the participants

\begin{tabular}{|c|c|c|c|c|c|c|c|c|}
\hline \multirow{2}{*}{$\begin{array}{l}\text { Variables } \\
\text { Socio demographic }\end{array}$} & \multicolumn{8}{|c|}{ The perception of health beliefs \& barriers } \\
\hline & Total $\boldsymbol{n}=710$ & Correct perception $\boldsymbol{n}=540(\%)$ & OR & $95 \% \mathrm{Cl}$ & $\boldsymbol{P}$-value & $\mathrm{AOR}$ & $95 \% \mathrm{Cl}$ & $\boldsymbol{P}$-value \\
\hline Age group, year & & & & & 0.636 & & & \\
\hline $18-20$ & 389 & $288(74.04 \%)$ & Ref & & & & & \\
\hline $21-24$ & 292 & $229(78.42 \%)$ & 1.25 & $0.87-1.79$ & & & & \\
\hline $25-28$ & 18 & $13(72.22 \%)$ & 0.57 & $0.20-1.61$ & & & & \\
\hline $28+$ & 11 & $10(90.91 \%)$ & 1.54 & $0.33-7.23$ & & & & \\
\hline Gender & & & & & 0.711 & & & \\
\hline Male & 309 & $230(74.43 \%)$ & Ref & & & & & \\
\hline Female & 401 & $310(77.31 \%)$ & 1.16 & $0.83-1.65$ & & & & \\
\hline Residence & & & & & 0.088 & & & \\
\hline Urban & 469 & $363(77.40 \%)$ & Ref & & & & & \\
\hline Rural & 241 & $177(73.44 \%)$ & 0.94 & $0.66-1.36$ & & & & \\
\hline Economic status & & & & & 0.344 & & & \\
\hline High & 43 & $34(79.07 \%)$ & Ref & & & & & \\
\hline Middle & 625 & 469 (75.04\%) & 1.46 & $0.74-2.86$ & & & & \\
\hline Low & 42 & 37 (88.10\%) & 0.90 & $0.36-2.23$ & & & & \\
\hline Civil status & & & & & 0.846 & & & \\
\hline Single & 589 & 447 (75.89\%) & Ref & & & & & \\
\hline Coexistent & 63 & $47(74.60 \%)$ & 3.30 & $1.06-5.95$ & & & & \\
\hline Divorced & 6 & $4(66.67 \%)$ & 2.28 & $1.06-4.91$ & & & & \\
\hline Married & 52 & $42(80.77 \%)$ & 0.81 & $0.44-1.49$ & & & & \\
\hline Field of study & & & & & 0.015 & & & 0.000 \\
\hline Non health sciences & 424 & 308 (72.64\%) & Ref & & & Ref & & \\
\hline Health sciences & 286 & 232 (81.11\%) & 1.61 & $1.12-2.32$ & & 1.67 & $1.15-2.41$ & \\
\hline Academic year & & & & & 0.016 & & & 0.002 \\
\hline 1st year & 232 & $158(68.10 \%)$ & Ref & & & Ref & & \\
\hline 2nd year & 249 & $203(81.53 \%)$ & 1.80 & $1.18-2.73$ & & 1.88 & $1.23-2.87$ & \\
\hline 3rd year & 229 & $179(78.17 \%)$ & 1.53 & $1.01-2.32$ & & 1.52 & $1.00-2.31$ & \\
\hline Have you had sexual intercourse? & & & & & 0.151 & & & \\
\hline No & 228 & $173(75.88 \%)$ & Ref & & & & & \\
\hline Yes & 482 & $367(76.14 \%)$ & 1.39 & $0.97-1.99$ & & & & \\
\hline
\end{tabular}

While the analysis of association with the other socio demographic variables found that there was no statistically significant relationship.

The results from bivariate analysis with logistic regression, also showed that there was no significant statistical association between VCT uptake (dependent variable) and independent variables as: age of first sexual intercourse $(p=0.874)$, the number of sexual partners $(p=0.905)$ and sexual experience of participants $(p=0.065)$. So, for each number of declared sexual partners, over $70 \%$ of the students did not get tested for HIV.
According to the above analysis, only two variables (residence and academic year) can be entered into multivariate analysis using multinomial logistic regression. The findings indicated that the students from the rural area $(\mathrm{AOR}=0.50,95 \% \mathrm{CI}[0.30-0.82])$ and those of first academic year (AOR second/first year $=2.31,95 \% \mathrm{CI}$ [1.33-3.99], AOR third/first year $=1.18,95 \%$ CI $[0.65-$ 2.13]) were less likely to use HIV testing, which reinforce the results obtained from the bivariate analysis.

On the other hand, there was a significant statistical association between the variables "I would not go to a local clinic to be tested for HIV because then everyone 
Table 3 The relationship between student's knowledge on preventive methods and the perceived barrier

\begin{tabular}{|c|c|c|c|c|c|}
\hline \multirow{3}{*}{$\begin{array}{l}\text { Knowledge on } \\
\text { preventive } \\
\text { methods: } \\
\text { "Using the } \\
\text { condom during } \\
\text { the sexual act } \\
\text { may reduce } \\
\text { the risk of HIV } \\
\text { infection" }\end{array}$} & \multicolumn{5}{|c|}{$\begin{array}{l}\text { Perceived barrier } \\
\text { "Using a condom seems like an insult to my partner" }\end{array}$} \\
\hline & \multirow{2}{*}{$\begin{array}{l}\text { Correct } \\
\text { answer }\end{array}$} & \multirow{2}{*}{$\begin{array}{l}\text { Incorrect } \\
\text { answer }\end{array}$} & \multicolumn{3}{|c|}{ Bivariate analysis } \\
\hline & & & Total & OR & $95 \% \mathrm{Cl}$ \\
\hline Incorrect answer & 79 (11.13\%) & 81 (11.41\%) & 160 (22.54\%) & Ref & \\
\hline Correct answer & $139(19.57 \%)$ & 411 (57.89\%) & $550(77.46 \%)$ & 0.35 & $0.24-0.50$ \\
\hline Total & 218 (30.70\%) & 492 (69.30\%) & 710 (100.00\%) & & \\
\hline
\end{tabular}

$P$-value: $p=0.000 \leq 0.05$

would know my status" and "VCT uptake" $(p=0.012)$ shown in Table 5. Additionally, the findings revealed that $81 \%$ of students who had a correct barrier's perception concluded that would not get tested for HIV. Referring to the bivariate regression analysis the students who had correct perception about barrier to HIV testing were $44 \%$ less likely to use VCT service as compared to their counterparts. $(\mathrm{OR}=0.56 ; 95 \% \mathrm{CI}[0.36-0.88])$.

\section{Discussion}

In the present study, the perception of health beliefs and barriers shows a satisfactory result and comparable to other studies $[17,23]$. Only $24 \%$ of the students have incorrect perceptions. It is very interesting the fact that the higher percentage of the incorrect answers of the participants was found to be related to the feeling of being insulted of one partner when the other suggested the use of condom during the sexual act. This feeling is considered in literature as a component of the perceived barriers based on Health Beliefs Model related to HIV/ AIDS and is considered to be one of the factors that affect the condom use [12, 24, 25]. In order to better analyze this factor in our study, we assessed the association between students knowledge about condom use as a preventive method and the barriers that may interfere on its use. There is a significant statistical association between the two above variables $(p<0.000)$ that is consistent with other studies $[13,26]$ which found that the perception of barriers was statistically related to the reduction of the condom use among university students.

In terms of health beliefs related to HIV infection, our study found that participating students were more likely to have sexual intercourse with more than one partner, without being afraid of HIV infection, pretending that they should be worried only when they have serious clinical signs. This finding indicates that a proportion of students are engaged in risky sexual behaviours that may expose them to risk of contracting STD including HIV infection. Interestingly, a significant proportion of students believe the misconception regarding HIV diagnosis, including that having an HIV test within 1 week of risk behaviour will tell if a person has HIV. These findings are reflected in similar other studies [27] that also show limited knowledge on this issue, which raises the need to have informing and preventing ongoing activities. About a third of the students believed that those who contracted HIV through illegal behaviour should not be treated in hospital and clinics. This may indicate that negative beliefs can contribute to continued stigma towards key at-risk populations and may be a barrier to HIV prevention efforts.

In relation to socio-demographic factors, we observed a significant correlation between health beliefs \& barriers and academic year, which is similar to international studies. These findings showed that the students of second and third year were more likely to have correct perceptions that is probably because the university curriculum structure teaches HIV topic in the 2nd year and beyond $[20,27]$. While it is encouraging to note that health science students and those with sexual experiences have more correct beliefs and attitudes related to HIV, which is consistent with previous studies [20, 27, 28].

In addition, the incorrect perception found to have the single students followed by married ones. These results are consistent with those of Sarcar, which found out that the socio-cultural aspects and the beliefs regarding the sexual act serve as barriers or influence on the condom use in marriage relations or the married students in India, while in other countries as Brazil, Africa, Mexico etc. the fear of condom use shows the absence of faith within the couple, and acts as a barrier of not using the condom from these couples [26] .

Counseling and testing for HIV/AIDS is another valued literature method which plays an important role in screening and keeping this infection under control. Our study analyzed this role and found out a low prevalence of voluntary testing for HIV among the students with sexual experience compared to other similar studies [18, 29]. In relation to demographic factors we notice that there is a slight change in males who have the tendency 
Table 4 The association between VCT uptake and explanatory factors among students with sexual experience

\begin{tabular}{|c|c|c|c|c|c|c|c|c|}
\hline \multirow{2}{*}{$\begin{array}{l}\text { Variables } \\
\text { Socio-demographic }\end{array}$} & \multicolumn{8}{|c|}{$\begin{array}{l}\text { Voluntary testing for HIV } \\
\text { Did you use VCT service? }\end{array}$} \\
\hline & $\begin{array}{l}\text { Total } \\
\boldsymbol{n}=482\end{array}$ & $\begin{array}{l}\text { Yes } \\
\boldsymbol{n}=106(\%)\end{array}$ & OR & $95 \% \mathrm{Cl}$ & $\boldsymbol{P}$-value & $\mathrm{AOR}$ & $95 \% \mathrm{Cl}$ & $\boldsymbol{P}$-value \\
\hline Age group, year & & & & & 0.403 & & & \\
\hline $18-20$ & 232 & $\begin{array}{l}54 \\
(23.28 \%)\end{array}$ & Ref & & & & & \\
\hline $21-24$ & 225 & $\begin{array}{l}48 \\
(21.33 \%)\end{array}$ & 0.89 & $0.58-1.39$ & & & & \\
\hline $25-28$ & 15 & $\begin{array}{l}1 \\
(6.67 \%)\end{array}$ & 0.24 & $0.03-1.87$ & & & & \\
\hline $28+$ & 10 & $\begin{array}{l}3 \\
(30.00 \%)\end{array}$ & 1.44 & $0.36-5.78$ & & & & \\
\hline Gender & & & & & 0.114 & & & \\
\hline Male & 290 & $\begin{array}{l}56 \\
(19.31 \%)\end{array}$ & Ref & & & & & \\
\hline Female & 192 & $\begin{array}{l}50 \\
(26.04 \%)\end{array}$ & 1.51 & $0.97-2.33$ & & & & \\
\hline Residence & & & & & 0.007 & & & 0.005 \\
\hline Urban & 316 & $\begin{array}{l}82 \\
(25.95 \%)\end{array}$ & Ref & & & Ref & & \\
\hline Rural & 166 & $\begin{array}{l}24 \\
(14.46 \%)\end{array}$ & 0.48 & $0.29-0.80$ & & 0.50 & $0.30-0.82$ & \\
\hline Economic status & & & & & 0.980 & & & \\
\hline High & 27 & $\begin{array}{l}6 \\
(22.22 \%)\end{array}$ & Ref & & & & & \\
\hline Middle & 426 & $\begin{array}{l}94 \\
(22.07 \%)\end{array}$ & 0.99 & $0.39-2.53$ & & & & \\
\hline Low & 29 & $\begin{array}{l}6 \\
(20.69 \%)\end{array}$ & 0.91 & $0.26-3.27$ & & & & \\
\hline Civil status & & & & & 0.280 & & & \\
\hline Single & 362 & $\begin{array}{l}71 \\
(19.61 \%)\end{array}$ & Ref & & & & & \\
\hline Married & 51 & $\begin{array}{l}16 \\
(31.37 \%)\end{array}$ & 2.11 & $0.38-11.72$ & & & & \\
\hline Divorced & 6 & $\begin{array}{l}2 \\
(33.33 \%)\end{array}$ & 1.56 & $0.84-2.87$ & & & & \\
\hline Coexistent & 63 & $\begin{array}{l}17 \\
(26.98 \%)\end{array}$ & 1.93 & $1.01-3.67$ & & & & \\
\hline Field of study & & & & & 0.459 & & & \\
\hline Non health sciences & 329 & $\begin{array}{l}72 \\
(21.88 \%)\end{array}$ & Ref & & & & & \\
\hline Health sciences & 153 & $\begin{array}{l}34 \\
(22.22 \%)\end{array}$ & 1.03 & $0.65-1.64$ & & & & \\
\hline Academic year & & & & & 0.001 & & & 0.003 \\
\hline 1st year & 144 & $\begin{array}{l}24 \\
(16.67 \%)\end{array}$ & Ref & & & Ref & & \\
\hline 2nd year & 170 & $\begin{array}{l}52 \\
(30.59 \%)\end{array}$ & 1.13 & $0.63-2.04$ & & 2.31 & $1.33-3.99$ & \\
\hline 3rd year & 168 & $\begin{array}{l}30 \\
(17.86 \%)\end{array}$ & 2.29 & $1.33-3.96$ & & 1.18 & $0.65-2.13$ & \\
\hline The age of first sexual intercourse & & & & & 0.087 & & & \\
\hline Less than 14 years old & 22 & 4 & Ref & & & & & \\
\hline
\end{tabular}


Table 4 The association between VCT uptake and explanatory factors among students with sexual experience (Continued)

\begin{tabular}{|c|c|c|c|c|c|c|c|c|}
\hline \multirow{2}{*}{$\begin{array}{l}\text { Variables } \\
\text { Socio-demographic }\end{array}$} & \multicolumn{8}{|c|}{$\begin{array}{l}\text { Voluntary testing for HIV } \\
\text { Did you use VCT service? }\end{array}$} \\
\hline & $\begin{array}{l}\text { Total } \\
\boldsymbol{n}=482\end{array}$ & $\begin{array}{l}\text { Yes } \\
\boldsymbol{n}=106(\%)\end{array}$ & OR & $95 \% \mathrm{Cl}$ & $\boldsymbol{P}$-value & $\mathrm{AOR}$ & $95 \% \mathrm{Cl}$ & $\boldsymbol{P}$-value \\
\hline & & $(18.18 \%)$ & & & & & & \\
\hline $15-18$ years & 249 & $\begin{array}{l}54 \\
(21.69 \%)\end{array}$ & 1.31 & $0.43-4.01$ & & & & \\
\hline 19 and older & 211 & $\begin{array}{l}48 \\
(22.75 \%)\end{array}$ & 1.37 & $0.45-4.23$ & & & & \\
\hline Number of sexual partners & & & & & 0.905 & & & \\
\hline 1 partner & 249 & $\begin{array}{l}56 \\
(22.49 \%)\end{array}$ & Ref & & & & & \\
\hline 2 partners & 102 & $\begin{array}{l}23 \\
(22.55 \%)\end{array}$ & 0.74 & $0.40-1.37$ & & & & \\
\hline 3 partners or more & 131 & $\begin{array}{l}27 \\
(20.61 \%)\end{array}$ & 0.88 & $0.54-1.42$ & & & & \\
\hline
\end{tabular}

to use VCT services more than females, which can be explained by the fact that albanian females hesitate to get tested for HIV due to the prejudice [30]. Contrary, other studies revealed a higher incidence of VCT uptake in females compared to males [31-34], probably because HIV effects last much longer on females and they are aware of this fact.

Indeed, HIV infection is equally dangerous for males and females, which means that the VCT uptake has the same level of importance for both genders. Meanwhile our study shows a statistically significant correlation between VCT practice and the residence of the participants with sexual experience. The students who live in the city have a higher probability to use VCT services than the ones who live in the rural areas. Referring the data from Universal Periodic Review of Albania 2018, the people who live in rural areas and the ones with lower income do not refer to the primary health care, because going to

Table 5 The association between VCT uptake and perceived barrier related to HIV testing

\begin{tabular}{|c|c|c|c|c|c|}
\hline \multirow{3}{*}{$\begin{array}{l}\text { Perceived } \\
\text { barrier } \\
\text { I would not } \\
\text { go to a clinic } \\
\text { to get tested } \\
\text { for HIV } \\
\text { because } \\
\text { everyone } \\
\text { would know } \\
\text { my HIV } \\
\text { status }\end{array}$} & \multicolumn{3}{|c|}{$\begin{array}{l}\text { VCT uptake } \\
\text { Have you been tested for HIV? }\end{array}$} & \multicolumn{2}{|c|}{$\begin{array}{l}\text { Bivariate } \\
\text { analysis }\end{array}$} \\
\hline & Yes & No & Total & OR & $95 \% \mathrm{Cl}$ \\
\hline & n (\%) & n (\%) & & & \\
\hline $\begin{array}{l}\text { Wrong } \\
\text { answer }\end{array}$ & 43 (8.92\%) & $\begin{array}{l}104 \\
(21.58 \%)\end{array}$ & 147 (30.50\%) & Ref & \\
\hline $\begin{array}{l}\text { Correct } \\
\text { answer }\end{array}$ & $63(10.07 \%)$ & $\begin{array}{l}272 \\
(56.43 \%)\end{array}$ & 335 (69.50\%) & 0.56 & $0.36-0.88$ \\
\hline Total & 106 (21.99\%) & $\begin{array}{l}376 \\
(78.01 \%)\end{array}$ & $\begin{array}{l}482 \\
(100.00 \%)\end{array}$ & & \\
\hline
\end{tabular}

$P$-value: $p=0.012 \leq 0.05$ health care institutions of a higher level asks for more money and time [35]. This is why the students who show a higher percentage of using VCT services are the ones that live in urban areas. The association between VCT practices and sexual behaviours shows that there is no statistical association, which means that the number of sexual partners and the age of first sexual intercourse do not have an impact on the fact that the students use VCT services or not. These results are in contrary to another study which showed that participants engaging in higherrisk sexual behaviours were more likely to be tested for HIV [36]. The results show that regardless the students' exposure to risky behaviours, there is a low number of voluntary testing for HIV even within the risky groups, similar to other studies previously carried out in Albania [35, 37]. Additionally, Albania is a traditional and patriarchal society in which stigma and discrimination play a significant role in preventing sexually active young people like tertiary level students accessing HIV testing for earlier diagnosis and treatment of HIV infection [30]. Regarding the fact that the barriers may have a negative impact on VCT practice, our study found that the fear of stigmatization may be one of them, which is similar to other studies [9, 17, 30, 32, 38]. As a whole, our results demonstrate that the students'beliefs may be barriers to universal access to use VCT services.

\section{Limitations}

There were several limitations to the study. The first one was related to the self-reported answers, which means that the results are affected to an over or under reporting. Moreover, the subject of the study consists of a delicate issue such as sexual behaviour. The second one is related to the development of the questionaire with closed questions, that prevents us from obtaining a more detailed information from the participants. Finally, the 
findings cannot be generalized to all university students in Albania because the sample was conveniently collected from one university in one city. Despite all of these limitations, we believe this study might be a reasonable source of information for researchers and policymakers.

\section{Conclusions}

The results of this study showed that the perceptions of barriers are good predictors of the preventive behaviours toward HIV infection. Nevertheless, this study discovered that "the feeling of insult" related to condom use and "the fear of personal consequence" related to HIV testing such as "fear of losing partner", were the main barriers that influence health services uptake, answering the research question of the study. In addition, the prevalence of VCT services resulted low and the fear of stigmatization was considered another potential barrier to non-use of them by students. The present study provides evidence to suggest that creating awareness about prevention and screening methods for HIV among student community, especially those from non-health sciences, could contribute to increased uptake of the VCT services, the condom use and to reduce the identified stigmatizing barriers. Identifying the barriers related to preventive and screening methods for HIV would help the health practitioners to implement better professional education, promote healthy sexual behaviors and increase access to quality services. This paper highlights the need to integrate stigma reduction with HIV prevention activities and the importance of investigating the impacts of the healthcare utilization among young people especially students with high-risk behaviors and those from rural areas which will constitute formidable challenges to the international community.

\section{Abbreviations \\ HIV: Human Immunodeficiency Virus; AIDS: Acquired Immunodeficiency Syndrome; VCT: Voluntary Counseling and Testing; ART: Antiretroviral Therapy; WHO: World Health Organization; ECDC: European Centre for Disease Prevention and Control; STD: Sexually Transmitted Diseases; KAPB: Knowledge, Attitude, Practice and Belief survey; SAS: Statistical Analysis System; Cl: Confidence of Interval; AOR: Adjusted Odds Ratio}

\section{Acknowledgments}

We thank all the students of the University of Vlora participating in the study for making this article possible! The corresponding author also thanks the co-authors of the article for their substantial contribution to draft the article or revise it critically for important intellectual content.

\section{Authors' contributions}

R.L. designed the study and was a major contributor to the writing of the manuscript. R.L. performed the data collection. A.B. performed statistical analysis of the data. R.L. and A.B. contributed to the interpretation of the results. Gj.Th. revised the manuscript for important intellectual content. All authors have read and approved the final manuscript.

\section{Funding}

This research received no specific grant from any funding agency in the public, commercial, or not-for-profit sectors.

\section{Availability of data and materials}

The datasets used and/or analysed during the current study are available from the corresponding author on reasonable request.

\section{Ethics approval and consent to participate}

The study was approved by the Research Ethics Committee of the University "Ismail Qemali" of Vlora, Prot. No. 93/2, on 04/04/2018 before the study commences. The application for ethical permission has outlined the details of the study. The ethics board approved the use of verbal consent of students to participate in this study. All aspects of this study have been performed in accordance with the Declaration of Helsinki for ethical standards. Respecting the ethics considerations, we informed the students for the goals of the study, the confidentiality and privacy making sure to explain that the questionnaire was anonymous and the data collected would not be identifiable. The explaining was done orally and written clearly on the first page of the questionnaire. The students gave oral consent to participate in the study and they had the rights to withdraw at any time.

\section{Consent for publication}

Not Applicable.

\section{Competing interests}

The authors declare that there is no conflict of interest.

\section{Author details}

${ }^{1}$ Faculty of Public Health, Department of Healthcare, University of Vlora "Ismail Qemali", Skelë, Rruga Kosova, 9400 Vlorë, Albania. ${ }^{2}$ Orthodox Clinic Medical Center, Tirana, Albania. ${ }^{3}$ University of Vlora "Ismail Qemali", Vlorë, Albania.

Received: 15 April 2020 Accepted: 20 August 2020

Published online: 27 August 2020

\section{References}

1. Shao Y, Williamson C. The HIV-1 epidemic: low- to middle-income countries. Cold Spring Harb Perspect Med. 2012;2(3):a007187. https://doi.org/10.1101/ cshperspect.a007187.

2. Baylies C, Bujra, J. AIDS, Sexuality, and Gender in Africa: Collective Strategies and Struggles in Tanzania and Zambia. H-S Africa, H-Net Reviews. 2004:xviii + 222 pp, ISBN 978-1-84142-027-1. http://www.h-net.org/reviews/showrev. php?id=9381.

3. UNAIDS Data. Retrieved from: http://www.unaids.org/sites/default/files/ media_asset/20170720_Data_book_2017_en.pdf. [Accessed 24 Dec 2017].

4. European Centre for Disease Prevention and Control/WHO Regional Office for Europe, 2017 HIV/AIDS surveillance in Europe 2017. Available at: https:// ecdc.europa.eu/sites/portal/files/documents/20171127Annual_HIVReport_ Cover\%2BInner.pdf. [Accessed 24 Dec 2017].

5. UNAIDS Data. Retrieved from: www.unaids.org/en/resources/documents/2 018/unaids-data-2018. [accessed 22 Mar 2019].

6. Global summary of the AIDS epidemic (2017). World Health Organization website. http://www.who.int/gho/hiv/en/. [Accessed 24 Dec 2017].

7. Shaw G, Varentsov I. The impact of transition from global fund support to governmental funding on the sustainability of harm reduction programs. A case study from albania eurasian harm reduction network. Available at: Albania - ICASO icaso.org/wp-content/uploads/2016/10/Albania-case-study1.pdf [accessed 22 Mar 2019].

8. Burazeri G, Roshi E, Tavanxhi N, Rrumbullaku L, Dasho E. Knowledge and attitude of undergraduate students in Tirana, Albania, towards sexually transmitted infections. Croat Med J. 2003:44(1):86-91 PMID: 12590435.

9. Ndabarora E, Mchunu G. Factors that influence utilisation of HIV/AIDS prevention methods among university students residing at a selected university campus. Saharaj J. 2014;11(1):202-10. https://doi.org/10.1080/ 17290376.2014.986517.

10. Burazeri G, Roshi E, Tavanxhi N. Sexual Practices of Undergraduate Students in Tirana. Albania. Croat Med J. 2003;44(1):80-5.

11. Peltzer K. Factors Affecting Condom use Among South African University Students. East Afr Med J. 2000 Jan;77(1):46-52 PMID: 10944840.

12. Katikiro E, Njau B. Motivating Factors and Psychosocial Barriers to Condom Use among out-of-School Youths in Dar es Salaam, Tanzania: A Cross Sectional Survey Using the Health Belief Model. ISRN AIDS. 2012:2012: 170739. Published 2012 Sep 27. https://doi.org/10.5402/2012/170739. 
13. Rooy GV, Mufune P, Indongo N, Matengu K, Libuku E, Schier Ch. Factors affecting safe sex practices among first year students at the University of Namibia: A Health Belief Model Perspective. European Scientific Journal /Special/ edition.2014 ISSN: 1857 - 7881 (Print) e - ISSN 1857- 7431. DOl: https://doi.org/10.19044/esj.2014.v10n10p\%25p.

14. Addis Z, Yalew A, Shiferaw $Y$, et al. Knowledge, attitude and practice towards voluntary counseling and testing among university students in North West Ethiopia: a cross sectional study. BMC Public Health. 2013;13:714. Published 2013 Aug 2. doi. https://doi.org/10.1186/1471-2458-13-714.

15. Strategic Document on Reproductive Health 2009-2015. Albanian Ministry of Health. http://www.nationalplanningcycles.org/sites/default/files/country_ docs/Albania/strategic_document_on_reproductive_health_2009-2015.pdf [Accessed 24 Dec 2017]

16. Institute of Statistics, Institute of Public Health, and ICF. 2018. Albania Demographic and Health Survey 2017-18. Tirana, Albania. Albania DHS, 2017-18 - Final Report (English). [accessed 30 Mar 2020].

17. Khalifa AFM, Eltayeb EM, Alawad AAMA. HIV-Related Stigma as Barrier to Voluntary Counselling and Testing among University Students in Sudan. Int Journal of Public Health Res. 2014;2(4):33-6 Available from:http://www. openscienceonline.com/journal/ijphr [accessed 22 Mar 2019].

18. Mulu A, Abera B, Knowledge YM. Attitude and Practices on HIV/AIDS among Students of Bahir Dar University. Science. J Public Health. 2014;2(2): 78-86. https://doi.org/10.11648/j.sjph.20140202.16.

19. Carey MP, Morrison-Beedy D, Johnson BT. The HIV-Knowledge Questionnaire: Development and Evaluation of a Reliable, Valid, and Practical Self-Administered Questionnaire. Aids Behav. 1997;1:61-74 attitudes and beliefs about HIV infection.

20. Alawad M, Alturki A, Aldoghayyim A, Alrobaee A, Knowledge AM. Attitudes, and Beliefs about HIV/AIDS and People Living with HIV among Medical Students at Qassim University in Saudi Arabia. Int J Health Sci (Qassim). 2019;13(5):22-30.

21. Zagumny MJ, Brady DB. Development of the AIDS Health Belief Scale (AHBS). AIDS Educ. P. 1998;10:173-9.

22. Wiklander M, Brännström J, Svedhem V, Eriksson LE. Development and psychometric testing of a barriers to HIV testing scale among individuals with HIV infection in Sweden; The Barriers to HIV testing scale-Karolinska version. Health Qual Life Outcomes. 2015;13:185. Published 2015 Nov 19. doi. https://doi.org/10.1186/s12955-015-0381-7.

23. Bulduk S, Kececi A. Condom-related beliefs among Turkish university students. Int J Human Sci. 2013;10(1):173-81.

24. Basavaraj KH, Navya MA, Rashmi R. Quality of life in HIV/AIDS. Indian J Sex Transm Dis AIDS. 2010;31(2):75-80. https://doi.org/10.4103/0253-7184.74971.

25. M A, Sharma M, Bernard AL, Rojas-Guyler L, Wang LL. Using the Health Belief Model to Determine Safer Sexual Behavior among African Immigrants. J Health Care Poor Underserved. 2013 Feb;24(1):120-34. https://doi.org/10. 1353/hpu.2013.0020.

26. Sarkar NN. Barriers to condom use. Eur J Contracept Reprod Health Care. 2008 Jun;13(2):114-22. https://doi.org/10.1080/13625180802011302.

27. Lui PSC, Sarangapany J, Begley K, Coote K, Kishore K. Medical and Nursing Students Perceived Knowledge, Attitudes, and Practices concerning Human Immunodeficiency Virus. ISRN Public Health. 2014:9. https://doi.org/10.1155/ 2014/975875.

28. Maimaiti N, Shamsuddin K, Abdurahim A, Tohti N, Maimaiti R. Knowledge, Attitude and Practice Regarding HIV/AIDS among University students in Xinjiang. Global J Health Sci. 2010;2:51. https://doi.org/10.5539/gjhs.v2n2p51.

29. Oppong Asante K. HIV/AIDS knowledge and uptake of HIV counselling and testing among undergraduate private university students in Accra, Ghana. Reprod Health. 2013;10:17. Published 2013 Mar 28. https://doi.org/10.1186/ 1742-4755-10-17.

30. Bozicevic I, Brown A, Delpech V, Dvoriak S. HIV in Albania: An Epidemiological Review. World Health Organization-Regional Office for Europe 2014. Retrieved from www.euro.who.int/HIV-in-Albania-A-NationalProgramme-Report-Final.pdf [accessed 22 Mar 2019].

31. Oguegbu A. Investigation of Relationship between Sociodemographic Factors and HIV Counseling and Testing among Young People in Nigeria. Adv Infect Dis. 2016;6(1):24-31. https://doi.org/10.4236/aid.2016.61004 https://www.researchgate.net/publication/299344162_Investigation_of_ Relationship_betwenSociodemographic_Factors_and_HIV_Counseling_and_ Testing_HCT_among_Young_People_in_Nigeria [accessed 22 Mar 2019].

32. Abdu O, Teshome G, Dereje M, Girma A, Daniel K, Agizie A. Knowledge, attitude, practice and associated factors of voluntary counseling and testing for HIV/AIDS among Wolkite university students in Ethiopia. JAHR Journal of AIDS and HIV. 2017;9(5):98-105. https://doi.org/10.5897/JAHR2015.0362 ISSN 2141-235.

33. Fikadie G, Bedimo M, Alamrew Z. Prevalence of Voluntary Counseling and Testing Utilization and Its Associated Factors among Bahirdar University Students. Adv Prev Med. 2014;2014:906107. https://doi.org/10.1155/2014/ 906107.

34. Sanga Z, Kapanda G, Msuya S, Mwangi R. Factors influencing the uptake of Voluntary HIV Counseling and Testing among secondary school students in Arusha City, Tanzania: a cross sectional study. BMC Public Health. 2015;15: 452. Published 2015 May 2. https://doi.org/10.1186/s12889-015-1771-9.

35. Universal Periodic Review of Albania-ACPD [accessed 22 Mar 2019]. acpd. org.al/wpcontent/uploads/2018/10/SRI-raport-Albania_opt.pdf.

36. Caldeira KM, Singer BJ, O'Grady KE, Vincent KB, Arria AM. HIV testing in recent college students: prevalence and correlates. AIDS Educ Prev. 2012; 24(4):363-76. https://doi.org/10.1521/aeap.2012.24.4.363.

37. Rjepaj K, Bani R. HIV/AIDS Monitoring and Evaluation Systems Strengthening for the National AIDS Program in Albania. Mater Sociomed. 2013;25(4):2736. https://doi.org/10.5455/msm.2013.25.273-276.

38. Meiberg AE, Bos AE, Onya HE, Schaalma HP. Fear of stigmatization as barrier to voluntary HIV counselling and testing in South Africa. East Afr J Public Health. 2008 Aug:5(2):49-54 PMID: 19024410.

\section{Publisher's Note}

Springer Nature remains neutral with regard to jurisdictional claims in published maps and institutional affiliations.
Ready to submit your research? Choose BMC and benefit from:

- fast, convenient online submission

- thorough peer review by experienced researchers in your field

- rapid publication on acceptance

- support for research data, including large and complex data types

- gold Open Access which fosters wider collaboration and increased citations

- maximum visibility for your research: over $100 \mathrm{M}$ website views per year

At BMC, research is always in progress.

Learn more biomedcentral.com/submissions 